\title{
THE USE OF MERCURY-BASED MEDICAL DEVICES ACROSS CROATIAN HEALTHCARE FACILITIES
}

\author{
Nataša JANEV HOLCER ${ }^{1}$, Marija MARIČEVIĆ ${ }^{2}$, and Anamarija MIOČIĆ-JURAN ${ }^{3}$ \\ University of Zagreb, School of Medicine, Andrija Štampar School of Public Health, Zagreb ${ }^{1}$, Public Healthcare \\ Centre Slavonski Brod, Slavonski Brod², Put Bokanjca 98, Zadar ${ }^{3}$, Croatia \\ Received in October 2011 \\ CrossChecked in December 2011 \\ Accepted in December 2011
}

\begin{abstract}
In 2009, we conducted a survey to assess the use of mercury-based thermometers and sphygmomanometers and their disposal in Croatian healthcare facilities. The questionnaire addressing the use of mercury-based medical devices, waste management, preferences between mercury-based and electronic devices, and the knowledge on mercury toxicity was filled by ward nurses affiliated with 40 (71.4\%) out of 56 contacted healthcare facilities. Only one of these facilities had given up the use of mercury-containing medical devices at the time. As many as $84.6 \%$ of the nurses believed that broken devices did not increase the risk of mercury exposure, even though $90 \%$ claimed they were aware of mercury toxicity. In fact, $69.4 \%$ of the nurses preferred mercury-containing devices on account of their precision and reliability and because they received little training in the use of electronic devices.

Breaking of thermometers and sphygmomanometers is common in healthcare facilities. The number of broken thermometers and sphygmomanometers was estimated to 278 and five per month, respectively. Only $18(46.2 \%)$ of the surveyed healthcare facilities claimed to have had a proper disposal procedure for mercury from broken devices. Nurses, who most often handle these devices and collect mercury spills, are primarily exposed to mercury vapours via inhalation. Croatia has adopted the EU Directive 76/769/EEC intended to reduce mercury exposure in the living and working environment. Our survey suggests that all healthcare professionals need training in proper management of broken mercury-based medical devices, nurses in particular. To reduce the risk of exposure, all Croatian healthcare facilities should implement guidelines for staff protection and programmes to gradually replace mercury-based with electronic devices.
\end{abstract}

KEY WORDS: nurses, occupational exposure, sphygmomanometers, thermometers

Occupational exposure to toxic substances may have adverse health effects on healthcare professionals. They are exposed to a wide variety of mechanical, chemical, physical, and biological risks. These risks arise not only from the direct contact with the diseased, but also from unfavourable occupational settings and behavioural patterns at work (1). The first step in lowering these risks is to recognise them (2-5).

Elemental mercury $\left(\mathrm{Hg}^{0}\right)$ is one of the major toxic hazards directly associated with health care. The Agency for Toxic Substances and Disease Registry
(ATSDR) has ranked it the third most toxic substance (6). In the past, various forms of mercury were used to treat syphilis and worm infestations, and mercuric chloride solution was one of the first antiseptics (7). Industrial development triggered a more extensive use of mercury and mercury-based compounds, which were used for both diagnostic and therapeutic purposes. For example, $\mathrm{Hg}^{0}$ was used in oesophageal dilators and Cantor/Miller Abbott tubes. Today, mercury can still be found in amalgam fillings, reagents, lab chemicals, batteries, certain types of 
bulbs, fluorescent tubes, and a number of other products $(7,8)$. Due to its high density, air stability, and uniform heat-induced spreading, it has often been used for metric equipment, including thermometers, sphygmomanometers, and barometers (9).

At room temperature, $\mathrm{Hg}^{0}$ is a liquid that evaporates, unless sealed in a container such as a mercury-based medical device. Inhalation is the primary route of occupational exposure to $\mathrm{Hg}^{0}$ and about $80 \%$ is absorbed $(8,10)$. Mercury spills can penetrate flooring cracks and be hard to clean up. Even in small amounts such as from a broken thermometer, these spills can contaminate indoor air above the recommended levels and present an occupational risk, unless cleaned and properly removed (11).

Mercury-based medical devices such as thermometers and sphygmomanometers break often in healthcare facilities $(12,13)$. Among healthcare professionals, people who are most often exposed to $\mathrm{Hg}^{0}$ vapours are the nurses who handle these instruments on a daily basis for a number of years and are responsible for collecting spills $(1,14)$. A US study conducted by the National Institute for Occupational Safety and Health (NIOSH) in 1980 to 1983 estimated that occupational exposure to $\mathrm{Hg}^{0}$ occurred in as many as 67,551 professionals $(21,153$ of whom were women). Most were affiliated with healthcare facilities and chemical plants either as nurses or chemistry technicians (6).
$\mathrm{Hg}^{0}$ has no other than toxic effects on the human body $(10,15,16)$. In recognition of direct mercuryrelated adverse human health effects, programmes to reduce mercury use and encourage proper management and disposal of mercury-containing wastes have been implemented throughout the world. Both the United States and some EU countries have long abandoned a number of mercury-containing products and compounds. Whenever possible, mercury-based medical devices are being replaced with electronic and infrared equipment $(17,18)$.

The aim of this survey was to see how nurses in Croatia saw the use of mercury-based medical devices, the cleanup and disposal of $\mathrm{Hg}^{0}$ spills, and mercury exposure in their healthcare facilities.

\section{SUBJECTS AND METHODS}

The survey was performed in 2009 and included 519 nurses affiliated with $40(71.4 \%)$ of the 56 healthcare facilities we contacted and which were listed by the Croatian Ministry of Health and Social Welfare. These facilities included three clinical hospital centres, three clinical hospitals, two clinics, 17 general hospitals, 13 special hospitals, and two health resorts and medical rehabilitation centres. The questionnaire collected data on the use of mercurybased thermometers and sphygmomanometers, the

Table 1 Views on harmful mercury-related health effects and preferences in choosing medical devices, reported by the interviewed nurses

\begin{tabular}{lcc}
\hline Answers & Number of participants & Percentage of answers \\
\hline No additional exposure at workplace & 439 & 84.6 \\
\hline Additional exposure at workplace & 80 & 15.4 \\
\hline Total number of participants & $\mathbf{5 1 9}$ & $\mathbf{1 0 0}$ \\
\hline & 52 & 10.0 \\
\hline Hg is completely harmless & 40 & 7.7 \\
\hline Hg is slightly harmful & 151 & 29.1 \\
\hline Hg is profoundly harmful & 276 & 53.2 \\
\hline Hg is extremely harmful & $\mathbf{5 1 9}$ & $\mathbf{1 0 0}$ \\
\hline Total number of participants & & 69.4 \\
\hline & 360 & 30.6 \\
\hline Favour mercury-based thermometers & 159 & $\mathbf{1 0 0}$ \\
\hline Dislike mercury-based thermometers & $\mathbf{5 1 9}$ & 65.5 \\
\hline Total number of participants & & 34.5 \\
\hline & 340 & $\mathbf{1 0 0}$ \\
\hline Favour mercury-based sphygmomanometers & 179 & \\
\hline Dislike mercury-based sphygmomanometers & $\mathbf{5 1 9}$ & \\
\hline Total number of participants & & \\
\hline
\end{tabular}


number of broken mercury-based medical devices per month, and the disposal and management of broken devices. Ward nurses were asked to share their views about the health impact of mercury spills and their preference between mercury-based and electronic medical equipment. They were also asked whether they considered their occupational mercury exposure to be greater than the exposure of the rest of medical staff.

The nurses were all informed about the purpose of the study and its protocol and participated on a voluntary and anonymous basis. The study was approved by the Ethics Committee of each participating healthcare facility.

\section{RESULTS}

Mercury-based thermometers and sphygmomanometers were used in 39 of the 40 surveyed healthcare facilities. In these 39 facilities, electronic medical equipment was also used, but only in certain wards. Mercury-based devices had been fully abandoned and replaced with electronic devices in only one of the surveyed healthcare facilities.

\section{Knowledge on Hg toxicity and common patterns of mercury-based device use}

Table 1 shows answers on mercury toxicity and personal attitudes and preferences. Even though most were aware of mercury toxicity, they still preferred mercury-based over electronic equipment, as they found it more precise and reliable, if slower to read.

Table 2 shows the estimates about the number of broken thermometers a month. This figure ranged between 2 and 278. Yearly, this figure ranged between 4 and 3336.

The monthly number of damaged/broken sphygmomanometers ranged from 0 to 5 , and the annual figure ranged from 1 to 94 .

\section{Disposal and management of mercury-based medical devices}

Broken mercury-based medical devices and mercury spills were properly disposed of into separate containers and managed as hazardous chemical waste in only $18(46,2 \%)$ out of 39 respondent healthcare facilities. Only one healthcare facility fully abandoned the use of mercury devices. At the remaining 21 healthcare facilities, 81 of 259 wards (31.3\%) properly handled the spills, while the remaining 178 $(68.7 \%)$ disposed of $\mathrm{Hg}^{0}$ inappropriately. Inappropriate disposal methods included placing broken devices in containers for infectious waste $(65.17 \%)$, in containers originally meant for broken glass storage (18.54\%), in communal waste $(15.17 \%)$, pouring the spills down the drain $(0.56 \%)$, and storing broken devices together with cytostatic waste $(0.56 \%)$ (Figure 1$)$.

\section{DISCUSSION}

To increase the awareness of the hazards of mercury in healthcare facilities and the healthcare sector on the whole, the World Health Organization (WHO) has recommended regular monitoring and assessment of mercury use in these settings (18). The US Environmental Protection Agency (EPA) has recommended replacing mercury-containing medical devices with mercury-free alternatives.

The EU member states have recommended reducing the use of mercury-based medical equipment to reduce the adverse health effects of occupational mercury exposures. This survey has shown that mercury-based medical devices are used in virtually all Croatian healthcare facilities. By comparison, $46 \%$ of Irish healthcare facilities have completely abandoned these devices and switched to mercury-free alternatives (19).

Table 2 Estimated number of monthly broken thermometers in healthcare facilities divided in 5 groups

\begin{tabular}{lcc}
\hline Number of broken thermometers per month & \multicolumn{2}{c}{ Healthcare facilities } \\
\cline { 2 - 3 } & Number & Percentage \\
\hline 51 to 50 & 20 & 51.3 \\
\hline 100 & 7 & 17.9 \\
\hline 151 to 200 & 4 & 10.3 \\
\hline 251 to 300 & 5 & 12.8 \\
\hline
\end{tabular}




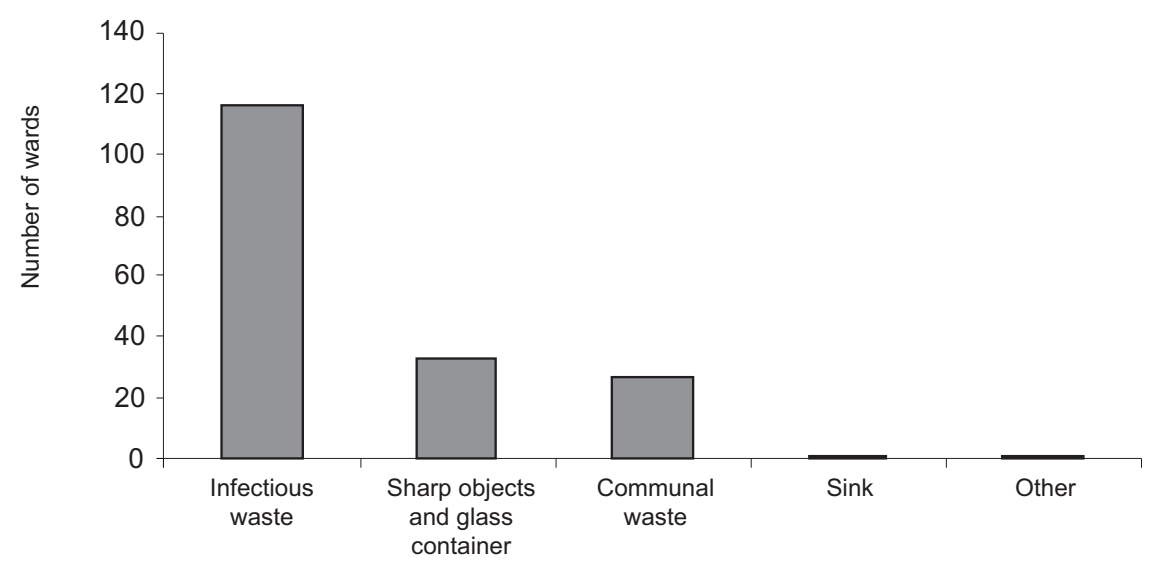

Figure 1 Ways of improper disposal of broken mercury thermometers among wards $(N=178)$ recorded in 21 hospitals

Many physicians and nurses believe that mercury sets "the gold standard" against which all alternative thermometers and sphygmomanometers should be compared. In our survey, $69.4 \%$ of the nurses preferred mercury-based medical devices. One reason for this preference might be that electronic devices currently in use are not fully adjusted to best serve hospital needs and are sometimes imprecise and unfit for repetitive measurements. The other reason is that the staff has not received proper training in electronic equipment maintenance and use, and that technical support leaves much to be desired.

However, Croatian healthcare facilities have started to switch to alternative devices such as infrared tympanic thermometers, which are far more precise and can quickly repeat measurements. It is reasonable to assume that, once they are satisfied with performance, nurses will more readily accept mercury-free devices.

A large number of studies have concluded that mercury-free measuring devices produce the same degree of accuracy as mercury devices, provided they are properly maintained and calibrated $(17,18)$.

The average amount of mercury to be found in thermometers spans from $0.5 \mathrm{~g}$ to $1.5 \mathrm{~g}$; wall-mounted and transportable sphygmomanometers contain $110 \mathrm{~g}$ to $200 \mathrm{~g}$ of mercury, while hospital lab thermometers contain $3 \mathrm{~g}$ to $4 \mathrm{~g}$ (20). According to some studies (8), the average number of thermometers broken in hospitals with 300 to 500 beds is 70 a month or 840 a year. This means that these hospitals release up to 3 kilograms of mercury into the environment a year and pose not only occupational, but also environmental threat. The number of broken thermometers in
Croatian hospitals with about 350 beds is estimated to between 160 and 180, or as many as 2,000 a year (21). By comparison, the Irish healthcare services witnessed no Hg spills at all in 2007 (19).

To get the broader picture of the issue, there are 31,578 nurses in Croatia alone. They play a crucial role in proper containment and management of mercury spills and mercury-containing waste (1). Yet, in our survey nurses of only 18 Croatian healthcare facilities reported proper disposal of broken mercurybased medical devices. Clearly, the rest requires urgent training minimise potential mercury exposure and improve the safety not only of the staff, but also of patients of all ages. In Croatia, only the occupational limits for mercury body burden have been determined, but not for the general population. Most of the regulatory standards are related to safety at work. For inorganic mercury the occupational limit is $0.05 \mathrm{mg} \mathrm{m}^{-3}$. The biological limit for blood mercury is $30 \mathrm{mg} \mathrm{L}^{-1}$ and for urine mercury $50 \mathrm{mg} \mathrm{g}^{-1}$ creatinine (22).

In Croatia, medical waste management is subject to the Waste Management Act (23), the Regulation on Waste Types (24), and the Guidelines for the Management of Waste Generated by Healthcare Services (25). Given the overall lack of knowledge on proper mercury disposal, it is likely that many mercury spills are not reported. Insufficient knowledge on managing, collecting, and waste disposal procedures to be followed after a mercury spill from broken mercury-based devices may result in the contamination of the working environment and substantial exposure to toxic mercuric vapours (1). Given that $84.6 \%$ of the surveyed nurses do not associate spills with their exposure to mercury, hazardous waste management 
should urgently be introduced to healthcare professional curricula. Our findings are supported by the Irish study reporting that over $50 \%$ of hazardous waste is inappropriately disposed of (19). Each ward should receive not only a proper training and procedures, but also sealable overpack containers for storing broken devices and spills. The collected waste should promptly be removed by a company duly licensed for hazardous waste management, contracted by the healthcare facility.

The latest Croatian regulations, adopted in April 2010 , bring a new inventory of hazardous chemicals that takes mercury-based medical devices off the free market (26) in line with the EU Directive 76/769/EEC (28). However, this will not stop their use in Croatia. They will be used as long as they function properly. The results of our survey suggest the need for monitoring and measuring mercury pollution across Croatian healthcare facilities. All healthcare professionals, nurses in particular, should receive training in mercury-related toxicity, potential sources of exposure, and proper management of mercurycontaining waste. All healthcare professionals should also receive training in the benefits of using mercuryfree alternatives. This can be orchestrated on the national level, following the current guidelines for the protection of healthcare professionals.

\section{REFERENCES}

1. Environmental Working Group (EWG). Nurses' Health and Workplace Exposures to Hazardous Substances [displayed 19 September 2011]. Available at http://www.ewg.org/sites/ nurse_survey/analysis/summary.php

2. Bogadi-Šare A.Zdravstveni djelatnici. [Healthcare workers, in Croatian]. In: Šarić M, Žuškin E, editors. Medicina rada i okoliša. Zagreb; Medicinska naklada; 2002. p. 571-5.

3. Bogadi-Šare A, Macan J, Pleština R, Turk R, Zavalić M. Kemijske štetnosti. [Chemical hazards, in Croatian]. In: Šarić M, Žuškin E, editors. Medicina rada i okoliša. Zagreb; Medicinska naklada; 2002. p. 162-6.

4. Bogadi-Šare A. Profesionalne bolesti i bolesti vezane uz rad, bolesti i životni okoliš. [Occupational diseases and illnesses related to work, illness and the environment, in Croatian] In: Šarić M, Žuškin E, editors. Medicina rada i okoliša. Zagreb; Medicinska naklada; 2002. p.125-8.

5. Žuškin E, Mustajbegović J, Dečković-Vukres V, Zavalić M, Bogadi-Šare A, Poplašen-Orlovac D, Prokić A, Bubaš M. Prepoznavanje potrebe zdravstvene skrbi o radnicima tijekom povijesti. [The Development of health care for workers through history, in Croatian]. Arh Hig Rada Toksikol 2006;57:201-12.

6. Agency for Toxic Substances and Disease Registry (ATSDR) Toxic Substances Portal - Mercury. Public Health Statement for Mercury 1999 [displayed 19 September 2011]. Available at http://www.atsdr.cdc.gov/PHS/PHS.asp?id=112\&tid=24

7. Pranjić N. Živa. [Mercury, in Croatian]. In: Pranjić N, editor. Medicina rada. Tuzla: Nacionalna i univerzitetska biblioteka Bosne i Hercegovine; 2007. p. 112-9.

8. Singh P. Mercury in healthcare: Clear and present danger. Toxics Alert [displayed 1 February 2011]. Available at http:// enews.toxicslink.org/feature-view.php?id=3

9. Filipović I, Lipanović S. Opća i anorganska kemija. Živa. [General and Inorganic Chemistry. Mercury, in Croatian]. Zagreb: Školska knjiga; 1995.

10. Baughman TA. Elemental mercury spills. Environ Healt Perspect 2006;114:147-52.

11. World Health Organization (WHO). Mercury in Health Care, Policy Paper [displayed 1 July 2011]. Available at http://www. who.int/water_sanitation_health/medicalwaste/ mercurypolpaper.pdf

12. Marinković N, Vitale K, Afrić I, Janev Holcer N. Javnozdravstveni aspekti gospodarenja opasnim medicinskim otpadom [Hazardous medical waste management as a public health issue, in Croatian]. Arh Hig Rada Toksikol 2005;56:2132.

13. Marinković, N, Vitale K, Janev Holcer N, Džakula A. Zbrinjavanje medicinskog otpada - zakonodavstvo i njegova provedba [Medical Waste Management: the Law and Its Application, in Croatian]. Arh Hig Rada Toksikol 2006;57:339-45.

14. Bahcecik N, Ozturk H. The occupational safety and health in hospitals from the point of nurses. Coll Antropol 2009:33:1205-14

15. Rom WN. Environmental and occupational exposures metals. In: Rom WN, editor. Environmental and occupational medicine. $4^{\text {th }}$ ed. Philadelphia: Lippincott, Williams\&Wilkins; 2007. p. 991-8.

16. United Nations Environment Programme and World Health Organisation (UNEP/WHO). Guidance for identifying populations at risk from mercury exposure. Geneva: WHO; 2008.

17. Health Care Without Harm (HCWH). Mercury [displayed 13 July 2011]. Available at http://www.noharm.org/europe/ issues/toxins/mercury/

18. Toward the Tipping Point: WHO-HCWH Global Initiative to Substitute Mercury-Based Medical Devices in Health Care. A Two-Year Progress Report [displayed 7 September 2011]. Available at http://www.noharm.org/lib/downloads/mercury/ Toward_the_Tipping_Point.pdf

19. McKeon M. The uses of mercury equipment and products in Irish healthcare. Ir Med J 2009;102:10-2.

20. United States Food and Drug Administration (US FDA). Medical Device Regulation [displayed 1 March 2011]. Available at http://www.registrarcorp.com/fda-medicaldevice/?lang=en

21. Janev Holcer N, Delalić A. Jesu li medicinske sestre izložene živi iz razbijenih mjernih instrumenata [Exposure of nurses to mercury from broken medical equipment, in Croatian]. Sigurnost 2011;53:371-9.

22. Pravilnik o graničnim vrijednostima izloženosti opasnim tvarima pri radu i o biološkim graničnim vrijednostima [Regulations on limit values for exposure to hazardous substances at work and on the biological limit values, in Croatian]. Narodne novine 13/2009. 
23. Zakon o otpadu [The waste management act, in Croatian]. Narodne novine 178/2004.

24. Pravilnik o vrstama otpada [Regulations on waste types, in Croatian]. Narodne novine 27/1996.

25. Naputak o postupanju s otpadom koji nastaje pri pružanju zdravstvene zaštite. [Instruction on the management of waste generated during healthcare delivery, in Croatian]. Narodne novine 50/2000.
26. Lista opasnih kemikalija čiji je promet zabranjen, odnosno ograničen [Inventory of hazardous chemicals list of forbidden or restricted hazardous chemicals, in Croatian]. Narodne novine 39/2010.

27. Council Directive 76/769/EEC relating to restriction on the marketing of certain measuring devices containing mercury. Off J Eur Union 2007;L 257:13-5. 


\section{Sažetak}

\section{UPOTREBA ŽIVINIH MJERNIH UREĐAJA U ZDRAVSTVENIM USTANOVAMA U HRVATSKOJ}

Živa je štetni čimbenik izravno povezan s provođenjem zdravstvene zaštite. Tijekom 2009. provedeno je istraživanje u zdravstvenim ustanovama RH, s ciljem procjene uporabe živinih mjernih instrumenata, toplomjera i tlakomjera te načina odlaganja razbijenih uređaja. Upitnik o uporabi živinih uređaja, zbrinjavanju otpada, sklonostima uporabi živinih, odnosno elektroničkih mjernih uređaja te pitanja o poznavanju toksičnosti žive, ispunile su odjelne medicinske sestre iz 40 (71,4\%) od 56 zdravstvenih ustanova. Samo u jednoj ustanovi živini se mjerni uređaji uopće ne rabe. Čak 84,6 \% ispitanica smatra da nisu dodatno izložene živi iz razbijenih uređaja, iako je $90 \%$ svjesno toksičnosti Hg. Zbog njihove preciznosti, pouzdanosti i nedostatka edukacije o uporabi i održavanju elektroničkih uređaja prednost uporabi živinih uređaja daje 69,4 \% medicinskih sestara. Razbijanje toplomjera i tlakomjera čest je incident u zdravstvenim ustanovama. Procijenjeni broj mjesečno razbijenih toplomjera bio je do 278, a razbijenih tlakomjera do 5. U samo 18 (46,2 \%) ustanova pravilno se odlagala živa iz razbijenih uređaja. Medicinske sestre koje najčešće rukuju uređajima i prikupljaju živu najizloženije su živinim parama putem inhalacije. U Hrvatskoj su doneseni pravni akti s namjerom smanjenja prisutnosti žive u životnom i radnom okolišu. Time je stupila na snagu EU direktiva 76/769/EEZ-a o smanjenju proizvodnje i prometa uređaja koji ju sadržavaju. Rezultati upućuju na potrebu edukacije svih zdravstvenih radnika, posebno medicinskih sestara, o zbrinjavanju razbijenih živinih mjernih uređaja. Radi smanjenja potencijalne izloženosti i osiguranja boljih zdravstvenih uvjeta na radnome mjestu sve hrvatske zdravstvene ustanove trebaju provoditi smjernice za zaštitu radnika i programe za smanjenje uporabe žive uporabom zamjenskih toplomjera i tlakomjera dostupnih na tržištu.

KLJUČNE RIJEČI: medicinske sestre, tlakomjeri, toplomjeri, profesionalna izloženost, zbrinjavanje otpada, živa

\section{CORRESPONDING AUTHOR:}

Nataša Janev Holcer

University of Zagreb, School of Medicine

Andrija Stampar School of Public Health

Department of Environmental and Occupational Health

4 Rockefeller St, HR-10000 Zagreb, Croatia

E-mail:njanev@snz.hr 